Materiales de Construcción

Vol. 69, Issue 333, January-March 2019, e176

ISSN-L: 0465-2746

https://doi.org/10.3989/mc.2019.11617

\title{
Use of fly ash and phosphogypsum for the synthesis of belite-sulfoaluminate clinker
}

\author{
S. Kramar ${ }^{\mathrm{a}} \bowtie$, L. Žibret ${ }^{\mathrm{a}}$, E. Fidanchevska ${ }^{\mathrm{a}}$, V. Jovanov ${ }^{\mathrm{b}}$, B. Angjusheva ${ }^{\mathrm{b}}$, V. Ducman ${ }^{\mathrm{a}}$ \\ a. Slovenian National Building and Civil Engineering Institute, (Ljubljana, Slovenia) \\ b. Ss. Cyril and Methodius University in Skopje, Faculty of Technology and Metallurgy, (Skopje, Macedonia) \\ Asabina.kramar@zag.si
}

\author{
Received 2 November 2017 \\ Accepted 24 May 2018 \\ Available on line 9 February 2019
}

\begin{abstract}
Fly ash and phosphogypsum were used as Naturally Occurring Radioactive Materials (NORM) by-products for the synthesis of belite-sulfoaluminate clinkers. The influence of raw mixture composition and firing temperature was investigated. Clinkers and cements were examined by X-ray powder diffraction and scanning electron microscopy with energy dispersive X-ray spectroscopy. The compressive strength of the cements was determined after 28 days. Clinker phases identified included ye'elimite, $\beta$-phase of belite, ternesite and gehlenite, while the main hydration product of the cement pastes was ettringite. The results showed that belitesulfoaluminate cements can be fabricated with a compressive strength of $45.9 \mathrm{~N} / \mathrm{mm}^{2}$ by firing the raw mixture (70 wt. \% marl, $10 \mathrm{wt} . \%$ bauxite and $20 \mathrm{wt} . \%$ phosphogypsum) at a temperature of $1320^{\circ} \mathrm{C} / 1 \mathrm{~h}$.
\end{abstract}

KEYWORDS: Clinker; Microstructure; Fly ash; Gypsum; Calcium sulphoaluminate

Citation/Citar como: Kramar, S.; Žibret, L.; Fidanchevska, E.; Jovanov, V.; Angjusheva, B.; Ducman, V. (2019) Use of fly ash and phosphogypsum for the synthesis of belite-sulfoaluminate clinker. Mater. Construcc. 69 [333], e176 https:// doi.org/10.3989/mc.2019.11617

RESUMEN: Uso de cenizas volantes y fosfoyesos en la síntesis de clínkeres belíticos de sulfoaluminatos. En este estudio se han utilizado cenizas volantes y fosfoyeso como Naturally Occurring Radioactive Materials (NORM) para la síntesis de clínkeres belíticos de sulfoaluminatos. Se ha investigado la influencia de la composición de la materia prima y de las diferentes temperaturas de cocción. Los clínkeres y cementos se examinaron mediante difracción de rayos X y microscopía electrónica de barrido equipada con espectroscopía de energía dispersiva de rayos X. Los valores de compresión de los cementos se determinaron a la edad de 28 días. Las fases constituyentes de los clínkeres se identificaron como ye'elimita, fase- $\beta$ de la belita, ternesita y gehlenita, mientras que el principal producto de hidratación de la pasta de cemento se identificó como ettringita. Los resultados muestran que los cementos belíticos de sulfoaluminatos pueden ser fabricados con una resistencia a compresión de 45.9 $\mathrm{N} / \mathrm{mm}^{2}$ mediante una cocción de la materia prima ( $70 \%$ en peso de marga, $10 \%$ de bauxita y $20 \%$ de fosfoyeso) a una temperatura de $1320^{\circ} \mathrm{C} / 1 \mathrm{~h}$.

PALABRAS CLAVE: Clínker; Microestructura; Ceniza volante; Yesos; Sulfoaluminato de calcio.

ORCID ID: S. Kramar (http://orcid.org/0000-0003-0483-9623); L. Žibret (http://orcid.org/0000-0002-0132-0896); E. Fidanchevska (http://orcid.org/0000-0003-2919-5916); V. Jovanov (http://orcid.org/0000-0001-7734-0757); B. Angjusheva (http://orcid.org/0000-0001-6661-1777); V. Ducman (http://orcid.org/0000-0002-6430-3305)

Copyright: (C) 2019 CSIC. This is an open-access article distributed under the terms of the Creative Commons Attribution 4.0 International (CC BY 4.0) License. 


\section{INTRODUCTION}

Ordinary Portland cement (OPC) is a widely used construction material that is manufactured via a highly energy-intensive process, producing large amounts of $\mathrm{CO}_{2}$ but also consuming large quantities of natural raw materials. Much effort has been made to reduce this $\mathrm{CO}_{2}$ footprint by utilising locally available secondary raw materials, replacing OPC clinker with mineral additives or the use of alternative fuels. Many studies have also focused on the development of new or alternative materials, one of which is belite-sulfoaluminate (BSA) cement. From an environmental and global warming perspective, such cements might reduce the impact caused by $\mathrm{CO}_{2}$ emissions not only due to their lower firing temperature (compared with that of OPC), but also due to the possibility of utilising alternative industrial waste and by-products as raw materials. BSA cement can be produced by combining various natural materials (limestone, clay, bauxite and gypsum) or by-products (fly ash, blast furnace slag, red mud, etc.) to provide the necessary $\mathrm{CaO}, \mathrm{SiO}_{2}, \mathrm{Al}_{2} \mathrm{O}_{3}$ and $\mathrm{SO}_{3}$ required for phase formation (1-6). Additionally, BSA cements contain high amounts of sulphur, which makes high sulphur-containing waste materials such as phosphogypsum suitable for their production $(7,8)$.

Studies investigating the production of BSA cements from waste materials or by-products are increasingly commonplace (9-14). Gallardo et al. (15) reported the fabrication of sulfoaluminate belite clinker containing $\mathrm{Ca}_{4} \mathrm{Al}_{6} \mathrm{O}_{12} \mathrm{SO}_{4}$ as its main phase from the mixture of aluminium dross, fluorogypsum, fly ash and $\mathrm{CaCO}_{3}$, with heat treatment applied in the temperature range from 1100 to $1400^{\circ} \mathrm{C}$. Three different cements were prepared using clinker powder mixed with $20 \mathrm{wt} . \%$ hemihydrate and various curing conditions. The main hydration phase was ettringite with typical acicular and hexagonal plates, with cement mechanical properties (compressive strengths of 40-47 $\mathrm{MPa}$ ) found to be comparable to those of OPC. Ren et al. (16) investigated the potential production of sulfoaluminate cement (SAC) via a high-performance method using $100 \%$ industrial solid waste, with the aim of reducing energy and natural resource consumption. By combining coal gangue, flue gas desulfurisation, aluminium slag and carbide slag, sintered at $1100-1300^{\circ} \mathrm{C}$, they obtained hydrated clinker specimens with compressive strengths of $59.5 \mathrm{MPa}$ and $75 \mathrm{MPa}$ after 3-day and 28-day curing, respectively. Belite-sulfoaluminate clinkers in general contain a minimum of $40-50 \mathrm{wt} . \%$ belite, $20-30 \mathrm{wt} . \%$ ye'elimite and ferrite phase, when the raw mixture is iron-rich (17); the complete phase assemblage can be formed at $1250^{\circ} \mathrm{C}(14,17,18)$. However, at enhanced firing temperatures the quantity of ye'elimite rises, which improves clinker reactivity. On the other hand, a high iron content can lower the optimum clinkering temperature (18), resulting in lower energy consumption.
If an anhydrite surplus is available, the ternesite phase can be formed at slow cooling below $1200^{\circ} \mathrm{C}(5,19-22)$. In high-aluminium clinkers in the presence of silicon, a nonreactive gehlenite phase can be formed $(4,13)$.

In cement pastes prepared from belite-sulfoaluminate clinker, a high early strength is ensured by the hydration of the ye'elimite phase and calcium sulfate source, from which large amounts of ettringite and aluminium hydroxide are produced $(3,23)$. Calcium sulfates can be sourced in cement as either as an anhydrite in the clinker, interground as gypsum after clinkering, or a combination of the two (1). After 28 days hydration, whereas the majority of the ye'elimite and calcium sulfate source will have reacted (24), the belite and ternesite phases react more slowly and contribute to the cement's long-term strength (20). The reactivity of belite depends strongly on its polymorphism (25). Moreover, it has been reported that even after 90 days, unactivated $\beta$-belite may remain mostly unhydrated (24) and may start to react only after 1 year of hydration (2). On the other hand, Bullerjahn et al. (20) reported the precipitation of strätlingite after 48 hours hydration, initiated during belite and ternesite hydration. Ferrite and calcium sulfate can form ettringite, portlandite and amorphous iron hydroxide, which contribute, slightly, to the longterm strength of a cement (25).

Cementitious materials present a valuable target for valorising various wastes, residues and by-products (coal fly ash and bottom ash, slag from the iron and steel industry, red mud...), offering the potential to both meet environmental challenges and accelerate the pursuit of industrial sustainability (26). Depending on their content of natural radionuclides, some are listed as naturally occurring radioactive materials (NORMs). Industrial wastes and by-products are used not only in blended cements or as mineral additives in concrete, but may also be added during clinkerisation itself, partially or totally replacing the virgin raw materials. One solution for recycling NORMs such as fly ash and phosphogypsum is the synthesis of belite-sulfoaluminate cement clinkers $(7,11,13,14)$. Commonly, the concentration of radionuclides originating from such residues is decreased in the resulting products due to the dilution effect $(26,27)$. It is also expected that the trend of NORM recycling will continue with their use not only in concrete, but also in cement and clinker (26).

The aim of this study was to investigate the possibility of substituting natural raw materials with industrial NORM by-products such as phosphogypsum and fly ash, in the synthesis of belitesulfoaluminate clinker. Thus, the phase composition and distribution in a series of belite-sulfoaluminate-based clinkers of different compositions were investigated at various heating profiles. In addition, the compressive strength and hydration products of cement pastes prepared from the clinkers were determined and discussed. 


\section{EXPERIMENTAL}

\subsection{Materials}

Clinker mixtures were prepared using natural raw materials (marl, bauxite) and two NORM by-products (phosphogypsum and siliceous fly ash). The chemical composition of the raw materials, given in Table 1, was determined using a Thermo Scientific ARL PERFORM'X Wavelength Dispersive X-Ray Fluorescence Spectrometer (WD XRF). Loss on ignition at $950^{\circ} \mathrm{C}$ was determined according to the standard EN 196-2, pt. 4.4.1 (28).

\subsection{Preparation of raw mixtures}

Three mixtures with different compositions were prepared by substituting bauxite with fly ash (A marl, bauxite, phosphogypsum; B - marl, bauxite/ fly ash, phosphogypsum; C - marl, fly ash, phosphogypsum); the amount of phosphogypsum remained constant in all mixtures (Table 2).

The raw mixtures were homogenised and ground in a planetary mill, before being passed through a $125 \mu \mathrm{m}$ sieve. A total of $350 \mathrm{~g}$ of material was prepared for each mixture. Two pressed pellets of $30 \mathrm{~g}$ each were prepared from each mixture using a Weber Pressen KIP 100 at $15 \mathrm{MPa}$. The clinker mixtures were subjected to the following heating regimes: (a) heating to $1120^{\circ} \mathrm{C}(\mathrm{T} 1), 1220^{\circ} \mathrm{C}(\mathrm{T} 2)$ or $1320^{\circ} \mathrm{C}$ (T3), (b) heating rate: $3^{\circ} \mathrm{C} / \mathrm{min}$, (c) holding time at the final temperature for $1 \mathrm{~h}$ and (d) natural cooling in a closed furnace.

TABLE 1. Chemical composition of raw materials (wt.\%).

\begin{tabular}{|c|c|c|c|c|}
\hline Parameter & Marl & Bauxite & Fly ash & Phosphogypsum \\
\hline $\mathrm{SiO}_{2}$ & 14.19 & 5.60 & 58.90 & 2.32 \\
\hline $\mathrm{CaO}$ & 38.52 & 0.35 & 4.33 & 32.40 \\
\hline $\mathrm{Al}_{2} \mathrm{O}_{3}$ & 5.04 & 87.20 & 20.80 & 0.18 \\
\hline $\mathrm{Fe}_{2} \mathrm{O}_{3}$ & 2.59 & 1.53 & 7.13 & 0,12 \\
\hline $\mathrm{MgO}$ & 2.39 & 0.22 & 2.11 & $<0.05$ \\
\hline $\mathrm{K}_{2} \mathrm{O}$ & 0.68 & 0.23 & 2.58 & 0.03 \\
\hline $\mathrm{Na}_{2} \mathrm{O}$ & 0.04 & b.d.l. & 0.65 & $<0.03$ \\
\hline $\mathrm{SO}_{3}$ & 0.21 & b.d.1. & 0.90 & 43.00 \\
\hline $\mathrm{P}_{2} \mathrm{O}_{5}$ & 0.02 & 0.24 & 0.23 & 0.13 \\
\hline $\mathrm{TiO}_{2}$ & 0.19 & 2.91 & 0.76 & 0.04 \\
\hline LOI & 35.37 & 0.16 & 1.48 & 19.50 \\
\hline
\end{tabular}

TABLE 2. Clinker mixtures (wt.\%).

\begin{tabular}{lcccc}
\hline Raw mixture & Marl & Bauxite & Fly ash & Phosphogypsum \\
\hline A & 70 & 10 & - & 20 \\
B & 70 & 5 & 5 & 20 \\
C & 70 & - & 10 & 20 \\
\hline
\end{tabular}

The chemical composition of raw mixtures before and after clinkering is shown in Tables 3 and 4, respectively. Samples were analysed using a Thermo Scientific ARL PERFORM'X Wavelength Dispersive X-Ray Fluorescence Spectrometer (WD XRF). Loss on ignition at $950^{\circ} \mathrm{C}$ was determined according to the standard EN 196-2, pt. 4.4.1 (28).

After firing, all clinkers were ground to below $125 \mu \mathrm{m}$ and the cements prepared by adding $10 \mathrm{wt} . \%$ gypsum (chemical grade, with a min. purity of $99 \%$, Kemika, Zagreb). Finally, the cement pastes were produced using a water/cement ratio of 0.6 .

\subsection{Methods}

The content of free lime (f-CaO) in the clinker samples was determined chemically after dissolving in ethanol-glycol (29).

The mineral composition of the clinkers and prepared cement pastes (after 28 days curing) was determined via X-ray diffraction in a PANalytical Empyrean X-ray diffractometer equipped with $\mathrm{CuK} \alpha$ radiation at $\lambda=1.54 \mathrm{~A}$. Samples were milled to a particle size of less than $50 \mu \mathrm{m}$. Data were collected at $45 \mathrm{kV}$ and a current of $40 \mathrm{~mA}$, over the $2 \theta$ range from $4^{\circ}$ to $70^{\circ}$, at a scan rate of $0.026^{\circ} 2 \theta /$ min. The obtained data were then analysed in the X'PertHighScore Plus diffraction software from PANalytical, using PAN-ICSD V3.4 powder diffraction files. Hydration processes were inhibited by solvent exchange, where crushed samples were immersed in $100 \mathrm{ml}$ of isopropanol for $15 \mathrm{~min}$. Finally, the samples were dried at $70^{\circ} \mathrm{C}$ for $60 \mathrm{~min}$.

Uncoated polished cross-sections of clinker samples were examined using a JEOL 5500 LV Scanning Electron Microscope (SEM) equipped with an Energy Dispersive X-ray spectrometer (EDS), at an accelerating voltage of $20 \mathrm{kV}$ and working distance of $20 \mathrm{~mm}$.

TABLE 3. Chemical composition of raw mixtures.

\begin{tabular}{lrrr}
\hline Mixture & \multicolumn{1}{c}{ A } & \multicolumn{1}{c}{ B } & \multicolumn{1}{c}{ C } \\
\hline $\mathrm{SiO}_{2}$ & 12.34 & 14.95 & 17.61 \\
$\mathrm{CaO}$ & 32.05 & 32.90 & 33.21 \\
$\mathrm{Al}_{2} \mathrm{O}_{3}$ & 13.83 & 9.79 & 6.10 \\
$\mathrm{Fe}_{2} \mathrm{O}_{3}$ & 1.80 & 2.09 & 2.38 \\
$\mathrm{MgO}$ & 1.99 & 2.02 & 2.16 \\
$\mathrm{~K}_{2} \mathrm{O}$ & 0.49 & 0.61 & 0.73 \\
$\mathrm{Na}_{2} \mathrm{O}$ & 0.27 & 0.21 & 0.29 \\
$\mathrm{SO}_{3}$ & 6.21 & 6.40 & 6.43 \\
$\mathrm{P}_{2} \mathrm{O}_{5}$ & 0.10 & 0.13 & 0.08 \\
$\mathrm{MnO}$ & 0.05 & 0.06 & 0.06 \\
$\mathrm{TiO}_{2}$ & 0.49 & 0.37 & 0.23 \\
$\mathrm{LOI}$ & 29.27 & 29.46 & 29.52 \\
\hline
\end{tabular}


TABLE 4. Chemical composition of raw mixtures heated at different temperatures.

\begin{tabular}{|c|c|c|c|c|c|c|c|c|c|}
\hline \multirow{2}{*}{$\begin{array}{l}\text { Mixture } \\
\mathbf{T}\left({ }^{\circ} \mathbf{C}\right)\end{array}$} & \multicolumn{3}{|c|}{$\mathbf{A}$} & \multicolumn{3}{|c|}{ B } & \multicolumn{3}{|c|}{ C } \\
\hline & 1120 & 1220 & 1320 & 1120 & 1220 & 1320 & 1120 & 1220 & 1320 \\
\hline $\mathrm{SiO}_{2}$ & 17.62 & 17.64 & 17.59 & 21.31 & 21.40 & 22.23 & 25.18 & 24.86 & 25.99 \\
\hline $\mathrm{CaO}$ & 45.82 & 46.20 & 45.49 & 46.79 & 47.51 & 48.80 & 47.30 & 46.84 & 49.75 \\
\hline $\mathrm{Al}_{2} \mathrm{O}_{3}$ & 19.06 & 19.56 & 19.93 & 13.91 & 14.05 & 14.56 & 8.88 & 9.06 & 9.18 \\
\hline $\mathrm{Fe}_{2} \mathrm{O}_{3}$ & 2.54 & 2.61 & 2.59 & 2.98 & 3.05 & 3.13 & 3.38 & 3.31 & 3.49 \\
\hline $\mathrm{MgO}$ & 2.65 & 2.70 & 2.58 & 2.86 & 2.93 & 2.99 & 3.06 & 3.11 & 3.24 \\
\hline $\mathrm{K}_{2} \mathrm{O}$ & 0.69 & 0.69 & 0.54 & 0.87 & 0.89 & 0.73 & 1.03 & 1.04 & 1.12 \\
\hline $\mathrm{Na}_{2} \mathrm{O}$ & 0.17 & 0.17 & b.d.1. & 0.22 & b.d.1. & 0.24 & 0.31 & 0.44 & 0.59 \\
\hline $\mathrm{SO}_{3}$ & 8.67 & 8.24 & 6.24 & 8.85 & 7.97 & 5.14 & 8.77 & 7.81 & 4.36 \\
\hline $\mathrm{P}_{2} \mathrm{O}_{5}$ & 0.13 & 0.21 & 0.13 & 0.14 & 0.13 & 0.19 & 0.13 & 0.13 & 0.15 \\
\hline $\mathrm{MnO}$ & 0.07 & 0.07 & 0.07 & 0.08 & 0.08 & 0.08 & 0.09 & 0.09 & 0.09 \\
\hline $\mathrm{TiO}_{2}$ & 0.72 & 0.73 & 0.73 & 0.53 & 0.53 & 0.57 & 0.35 & 0.33 & 0.38 \\
\hline LOI & 0.19 & 0.19 & 0.26 & 0.11 & 0.19 & 0.23 & 0.10 & 0.25 & 0.26 \\
\hline
\end{tabular}

TABLE 5. f-CaO content of clinker samples.

\begin{tabular}{|c|c|c|c|c|c|c|c|c|c|}
\hline Mixture & & $\mathbf{A}$ & & & B & & & C & \\
\hline $\mathrm{T}\left({ }^{\circ} \mathrm{C}\right)$ & 1120 & 1220 & 1320 & 1120 & 1220 & 1320 & 1120 & 1220 & 1320 \\
\hline $\mathrm{f}-\mathrm{CaO}(\%)$ & 0.13 & 0.11 & 0.11 & 0.10 & 0.23 & 0.18 & 0.27 & 0.13 & 0.11 \\
\hline
\end{tabular}

TABLE 6. Clinker phase composition, as obtained by X-ray powder diffraction. Legend: $-=$ undetected; $\operatorname{tr}=$ trace; $+=$ low proportion; $++=$ medium proportion; $+++=$ high proportion; $++++=$ predominant phase

\begin{tabular}{|c|c|c|c|c|c|c|c|c|c|}
\hline \multirow{2}{*}{$\begin{array}{l}\text { Clinker } \\
\text { Phase }\end{array}$} & \multicolumn{3}{|c|}{$\mathbf{A}$} & \multicolumn{3}{|c|}{ B } & \multicolumn{3}{|c|}{$\mathrm{C}$} \\
\hline & $1120^{\circ} \mathrm{C}$ & $1220^{\circ} \mathrm{C}$ & $1320^{\circ} \mathrm{C}$ & $1120^{\circ} \mathrm{C}$ & $1220^{\circ} \mathrm{C}$ & $1320^{\circ} \mathrm{C}$ & $1120^{\circ} \mathrm{C}$ & $1220^{\circ} \mathrm{C}$ & $1320^{\circ} \mathrm{C}$ \\
\hline$\beta$-belite & $\operatorname{tr} /+$ & + & ++ & + & + & ++ & + & + & ++ \\
\hline Ye'elimite & ++ & +++ & ++++ & ++ & ++ & +++ & + & $\operatorname{tr} /+$ & ++ \\
\hline Ternesite & ++ & ++ & - & ++ & ++ & - & +++ & +++ & - \\
\hline Gehlenite & ++ & ++ & - & ++ & ++ & - & +++ & +++ & - \\
\hline Ferrite & + & + & + & + & + & + & + & + & + \\
\hline Anhydrite & $\operatorname{tr}$ & $\operatorname{tr}$ & + & + & $\operatorname{tr} /+$ & + & + & + & + \\
\hline Periclase & + & $\operatorname{tr}$ & $\operatorname{tr} /+$ & $\operatorname{tr}$ & $\operatorname{tr}$ & $\operatorname{tr}$ & - & $\operatorname{tr}$ & $\operatorname{tr}$ \\
\hline Free-lime & $\operatorname{tr}$ & $\operatorname{tr}$ & $\operatorname{tr}$ & $\operatorname{tr}$ & $\operatorname{tr}$ & $\operatorname{tr}$ & + & $\operatorname{tr} /+$ & + \\
\hline Quartz & + & + & - & + & + & - & + & + & - \\
\hline
\end{tabular}

For the determination of cement compressive strength, the mixtures were cast into prismatic moulds of dimensions $10 \times 10 \times 25 \mathrm{~mm}$. The cement paste samples were demoulded $24 \mathrm{~h}$ after casting and cured until testing in sealed plastic bags under laboratory conditions at $21 \pm 2^{\circ} \mathrm{C}$. Compressive strength was determined after 28 days in two specimens per mixture using the ToniNORM Toni-Technic testing machine (Zwick) at a loading rate of $0.04 \mathrm{kN} / \mathrm{s}$.

\section{RESULTS AND DISCUSSION}

As each of the three raw clinker mixtures in Table 2 were fired at three different temperatures, the obtained clinkers were further characterised regarding their phase composition and microstructure.

\subsection{Clinker characterisation}

\subsubsection{Clinker mineralogy and $f-C a O$ content}

Clinker f-CaO content (Table 5) did not exceed $0.23 \%$, indicating that the available $\mathrm{Ca}$ in the raw mixtures was consumed during the burning process.

Table 6 displays the results of X-ray powder diffraction analysis for clinker mixtures A (no substitution of bauxite with fly ash), B (half of bauxite substituted with fly ash) and C (bauxite 

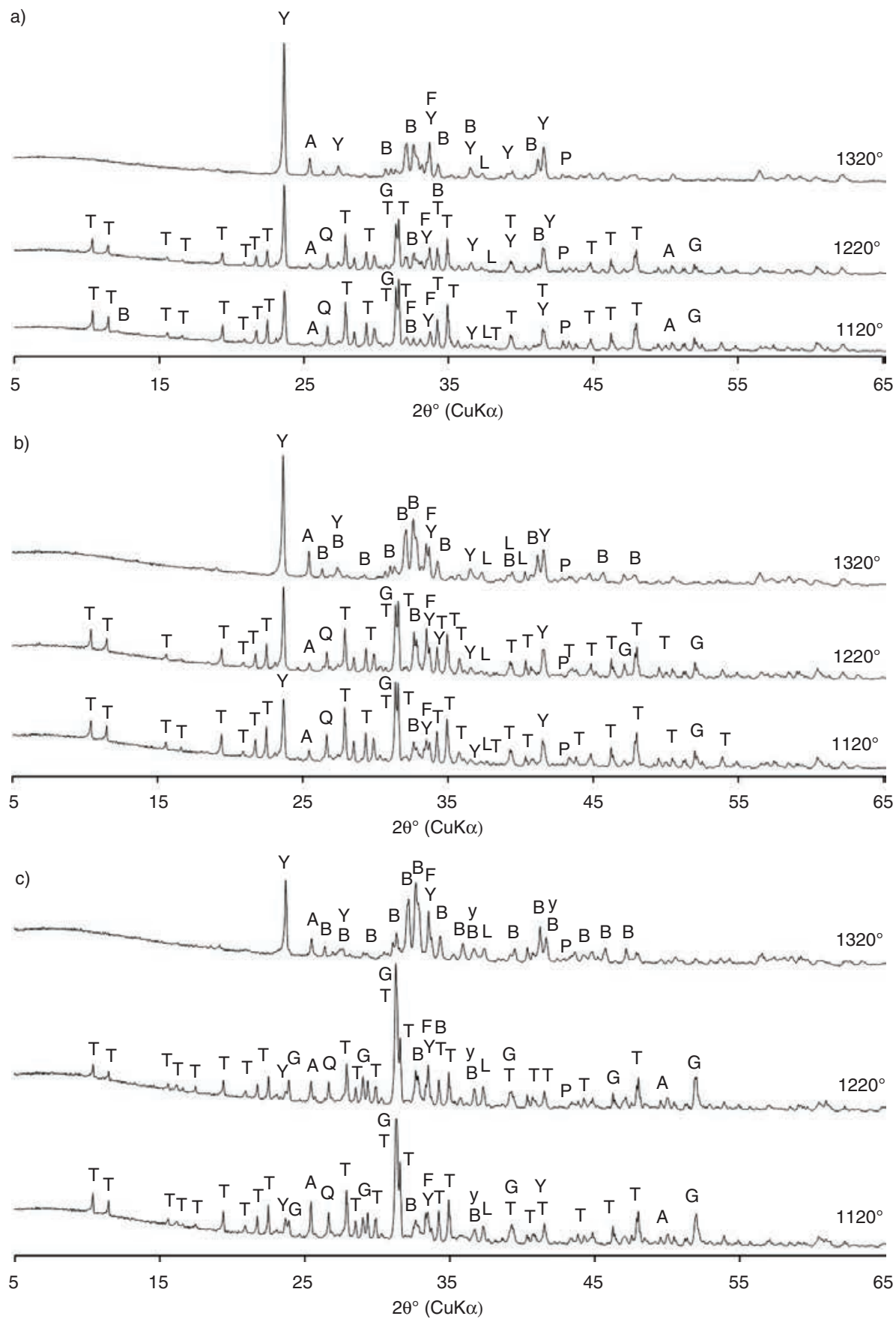

Figure 1. X-ray patterns of clinkers fired at $1120^{\circ} \mathrm{C}, 1220^{\circ} \mathrm{C}$ and $1320^{\circ} \mathrm{C}$ : a) Mixture A; b) Mixture B; c) Mixture C. Labels for clinker phases: $\mathrm{B}=\beta$-belite; $\mathrm{Y}=$ ye'elimite; $\mathrm{F}=$ ferrite; $\mathrm{G}=$ gehlenite; $\mathrm{T}=$ ternesite; $\mathrm{A}=$ anhydrite; $\mathrm{Q}=$ quartz; $\mathrm{L}=$ lime.

fully substituted with fly ash) fired at the three different temperatures, with the corresponding X-ray powder diffraction patterns shown in Figure 1. In all three mixtures the presence of the $\beta$ phase of belite $\left(\beta-\mathrm{C}_{2} \mathrm{~S}\right)$, orthorhombic and cubic ye'elimite $\left(\mathrm{C}_{4} \mathrm{~A}_{3} \overline{\mathrm{S}}\right)$, ternesite $\left(\mathrm{C}_{5} \mathrm{~S}_{2} \overline{\mathrm{S}}\right)$, gehlenite $\left(\mathrm{C}_{2} \mathrm{AS}\right)$, ferrite $\left(\mathrm{C}_{4} \mathrm{AF}\right)$ and anhydrite $(\mathrm{CS})$ was evident.

As can be seen in Figure 1, the amount of ye'elimite and belite in mixtures A and B increased with firing temperature. However, mixture A was characterised by a higher ye'elimite content and lower belite content than mixture $\mathrm{B}$. The presence of ternesite was evident at $1120^{\circ} \mathrm{C}$ and $1220^{\circ} \mathrm{C}$, but was completely absent at a clinkering temperature of $1320^{\circ} \mathrm{C}$ due to its decomposition into belite and anhydrite $(7,30)$. Ternesite is stable in the temperature range of $900-1200^{\circ} \mathrm{C}$ and is formed by reacting belite and anhydrite (31), a fact supported by 
the present study in which a slight increase in anhydrite content with firing temperature was observed. Additional phases recorded included gehlenite, which formed only at clinkering temperatures of $1120^{\circ} \mathrm{C}$ and $1220^{\circ} \mathrm{C}$, and ferrite, which was identified in both clinkers at all three clinkering temperatures. As a remnant of the raw material, quartz was present in smaller amounts in clinkers heated at $1120^{\circ} \mathrm{C}$ and $1220^{\circ} \mathrm{C}$. This indicates that the raw material had not reacted completely at $1220^{\circ} \mathrm{C}$, but had done so at $1320^{\circ} \mathrm{C}$. The presence of anhydrite at all firing temperatures suggests that more $\mathrm{SO}_{3}$ was present than was needed for the formation of ye'elimite (6).

Whereas only a very low amount of ye'elimite was observed in clinker mixture $\mathrm{C}$ heated at temperatures of $1120^{\circ} \mathrm{C}$ and $1220^{\circ} \mathrm{C}$, levels increased significantly at $1320^{\circ} \mathrm{C}$. Clinker mixture $\mathrm{C}$ was also characterised by a high amount of belite compared to the other two mixtures, increasing with rising clinkering temperature. As was observed for mixtures A and $\mathrm{B}$, ternesite and gehlenite were present in clinker mixture $\mathrm{C}$ at temperatures of $1120^{\circ} \mathrm{C}$ and $1220^{\circ} \mathrm{C}$. However, gehlenite levels were much higher in mixture $\mathrm{C}$ due to the large amount of silica found in the raw fly ash (Table 1). Ferrite was present at all three clinkering temperatures, while the amount of anhydrite in clinker mixture $\mathrm{C}$ decreased with increasing firing temperature. A small amount of quartz was found only in clinkers heated at $1120^{\circ} \mathrm{C}$ and $1220^{\circ} \mathrm{C}$.

The selected raw materials had a significant influence on the formation of major clinker phases. Clinker mixture A exhibited the best development of the ye'elimite phase at all three clinkering temperatures due to its high alumina content. In mixture B the ye'elimite phase was also clearly expressed, but at a lower ratio to belite with respect to mixture A. Mixture $\mathrm{C}$, in which bauxite was completely replaced by fly ash, was characterised by the lowest amounts of the ye'elimite phase due to the associated alumina deficit. However, levels significantly increased at $1320^{\circ} \mathrm{C}$, as this temperature was sufficient for the conversion of anhydrite and gehlenite into belite and ye'elimite (32). As a result, samples also exhibited decreased anhydrite and an absence of gehlenite at this temperature. The presence of anhydrite in all clinker samples indicates a surplus of $\mathrm{SO}_{3}$ in the raw mixtures. Consequently, at clinkering temperatures of $1120^{\circ} \mathrm{C}$ and $1220^{\circ} \mathrm{C}$ the reaction between belite and anhydrite led to the formation of ternesite $(17,18$, 20). Indeed, when both $\mathrm{SiO}_{2}$ and $\mathrm{SO}_{3}$ are high in the raw mix, ternesite forms easily (6). At $1320^{\circ} \mathrm{C}$ ternesite was not observed, while the amount of belite was at its highest among the three firing temperatures. This pattern can be explained by the decomposition of ternesite at temperatures above $1250^{\circ} \mathrm{C}(31$, $33,34)$. Belite and ternesite phases were dominant in clinker mixture $\mathrm{C}$, where the addition of fly ash provided larger quantities of silica. A clearly detectable amount of ferrite was evident in the two clinkers with added fly ash (mixtures B and C), due to the relatively high iron content of this raw material. Gehlenite was recorded together with ternesite at clinkering temperatures of $1120^{\circ} \mathrm{C}$ and $1220^{\circ} \mathrm{C}$ in all mixtures, with levels of both gradually increasing with a higher amount of fly ash in the raw mixture, i.e. from mixtures A to C. Neither ternesite nor gehlenite were observed at a temperature of $1320^{\circ} \mathrm{C}$.

\subsubsection{Clinker microstructure}

The phase distribution and microstructure of the clinkers were studied by SEM/EDS analysis.

According to this analysis, the clinkers of all three compositions heated at the lower clinkering temperatures $\left(1120^{\circ} \mathrm{C}\right.$ and $\left.1220^{\circ} \mathrm{C}\right)$ were highly porous and heterogeneous (Figure 2). Clinkerisation at $1220^{\circ} \mathrm{C}$ resulted in a slightly denser and semi-homogeneous texture, with a higher degree of crystallisation. However, phase composition was the same at both temperatures, with ternesite, belite, ye'elimite, gehlenite, ferrite and anhydrite all observed. Mixtures A and B were found to contain clusters comprising round grains of aluminium oxide, as well as interstitial phases consisting of gehlenite and ferrite (Figure 3), neither of were present at $1320^{\circ} \mathrm{C}$, as sintering proceeded. The grains were absent in clinker mixture $\mathrm{C}$, due to the depletion of alumina in these samples and the incorporation of siliceous fly ash. Instead, ternesite formed clear anhedral grains, with laths of gehlenite clearly visible.

At $1320^{\circ} \mathrm{C}$, clinker texture was homogeneous with low porosity due to the progress of the sintering process (Figure 4). Ye'elimite and belite were the dominant phases, with the ferrite phase appearing as individual smaller grains. The amount of ye'elimite decreased clearly with a higher content of fly ash in the raw mixture. As determined by SEM/ EDS, higher amounts of iron were incorporated in the ye'elimite phase of mixtures B and $\mathrm{C}$, reflecting the introduction of iron-containing fly ash in the raw mixtures. Such incorporation can lead to iron solid solutions of the ye'elimite phase, which may in turn influence cement hydration kinetics (35, 36). In contrast, well-developed belite crystals were predominant in clinker mixture $\mathrm{C}$. Ternesite and gehlenite were not observed at this temperature, as also identified by X-ray powder diffraction.

\subsection{Characterisation of cement pastes}

Cements were prepared by adding 10 wt. $\%$ of gypsum to the ground clinker, with the cement pastes produced using a water/cement ratio of 0.6. Hardened pastes were then characterised in terms of their phase compositions and mechanical properties (compressive strength). 

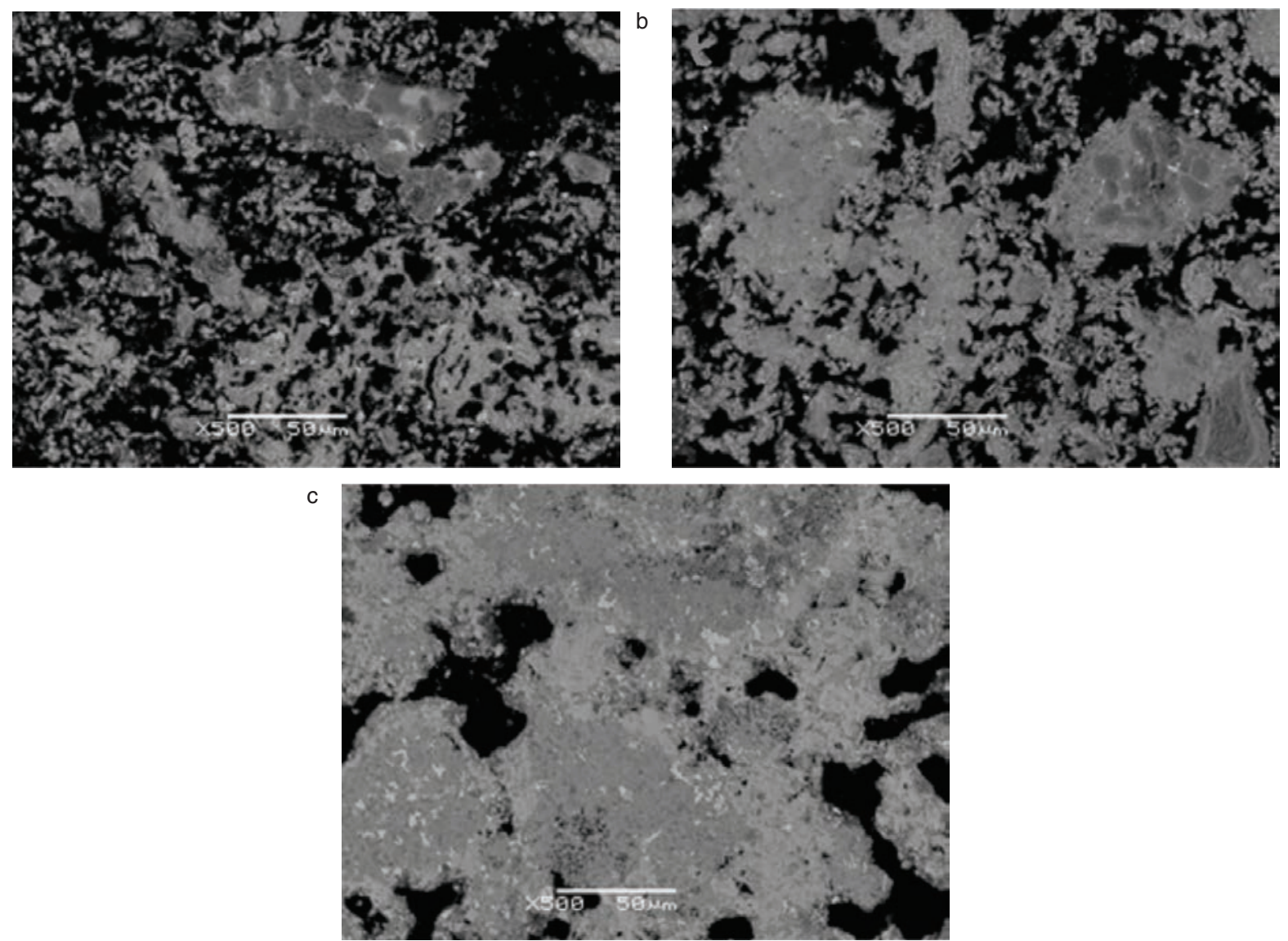

FIGURE 2. SEM/BSE photomicrographs showing the microstructural densification of clinker mixture A at sintering temperatures of (a) $1120^{\circ} \mathrm{C}$, (b) $1220^{\circ} \mathrm{C}$ and (c) $1320^{\circ} \mathrm{C}$.

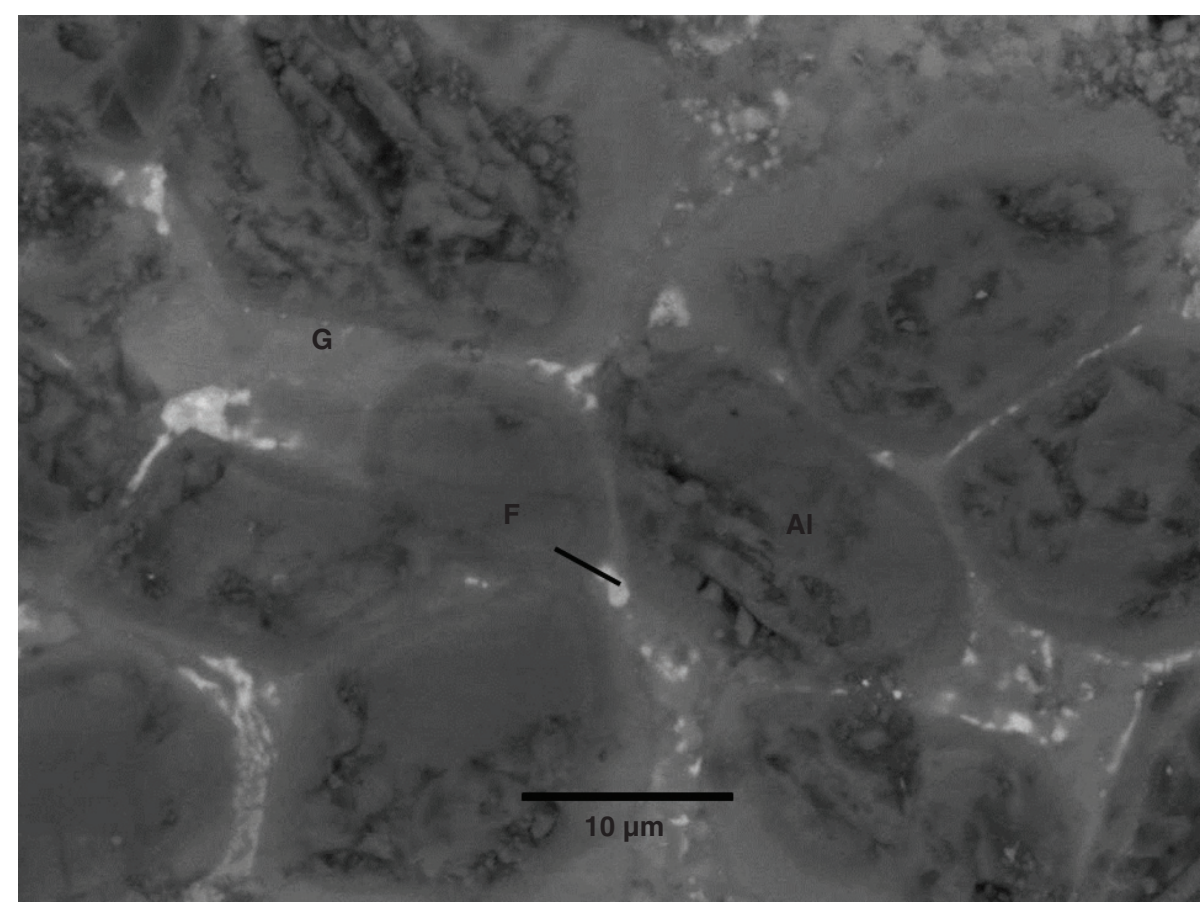

FIGURE 3. SEM/BSE photomicrograph of clinker mixture A heated at $1220^{\circ} \mathrm{C}$, showing rounded Al-enriched crystals. The interstitial phase consists of gehlenite $(\mathrm{G})$ and ferrite $(\mathrm{F})$. 

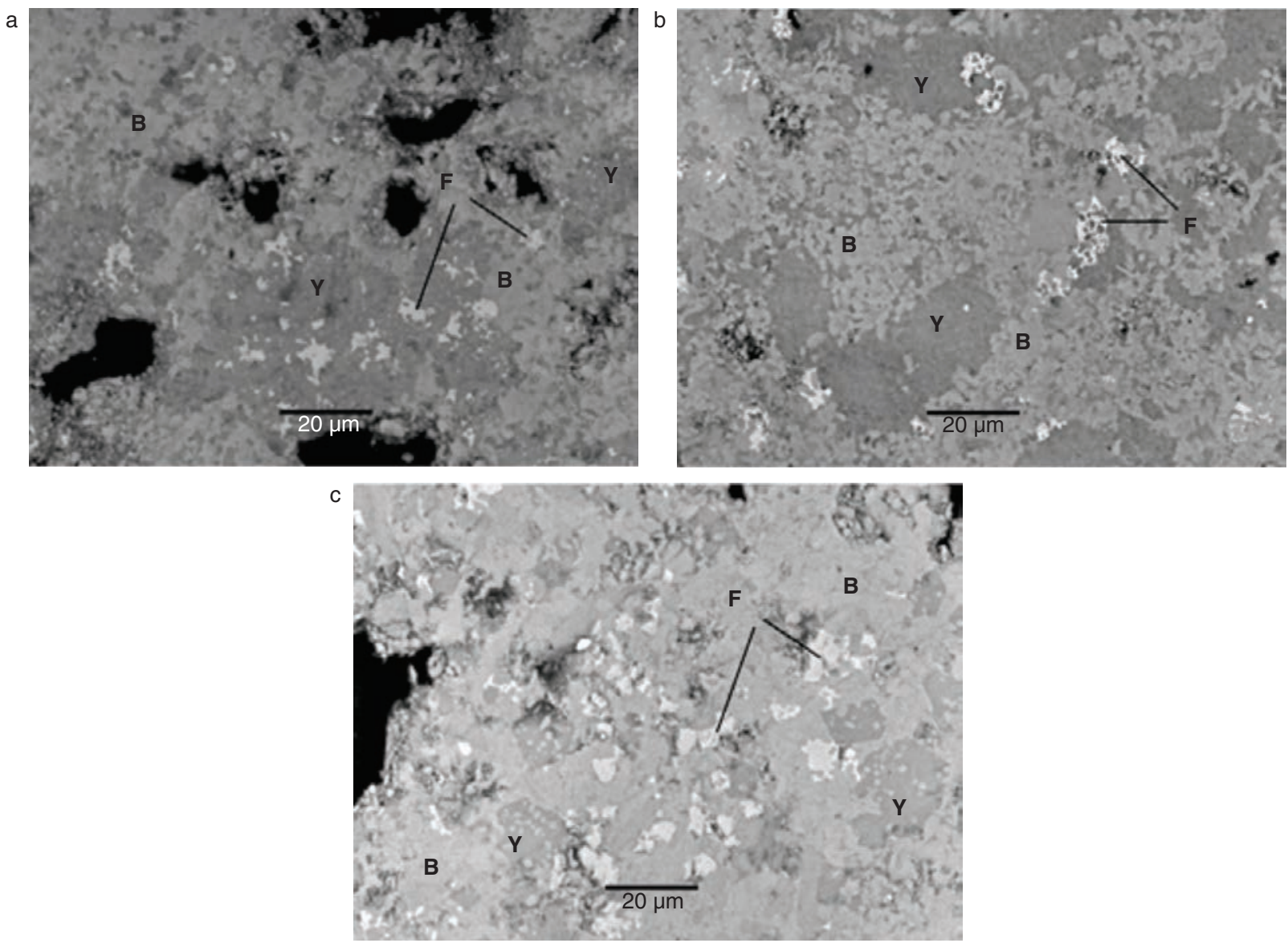

FIGURE 4. SEM/BSE photomicrographs of the polished sections of clinkers heated at $1320^{\circ} \mathrm{C}$. Microstructure of (a) clinker mixture A, (b) clinker mixture B and (c) clinker mixture C. Phases identified include belite (B), ye'elimite (Y) and ferrite (F).

\subsubsection{Phase composition of hydrated cements}

Figure 5 displays the phase composition of the cement pastes, prepared from the studied clinkers, after 28 days curing. The main hydration product was ettringite $\left(\mathrm{C}_{6} \mathrm{AS}_{3} \mathrm{H}_{32}\right)$, followed by unreacted gypsum $(\mathrm{C} \overline{\mathrm{S}} \mathrm{H})$ in varying amounts, as well as remnant clinker phases including belite $\left(\beta-\mathrm{C}_{2} \mathrm{~S}\right)$, ternesite $\left(\mathrm{C}_{5} \mathrm{~S}_{2} \overline{\mathrm{S}}\right)$, gehlenite $\left(\mathrm{C}_{2} \mathrm{AS}\right)$ and ye'elimite $\left(\mathrm{C}_{4} \mathrm{~A}_{3} \overline{\mathrm{S}}\right)$.

Regarding the cement pastes based on clinker mixture A (Figure 5a), ye'elimite was barely detected in all three samples, indicating that almost all ye'elimite was consumed in the formation of ettringite (23). In addition, almost all gypsum was consumed during the hydration process. A similar situation was observed for the cement pastes produced from clinker mixture B (Figure 5b), in which a gradual increase in the intensity of ettringite was recorded with clinkering temperature. This result is in accordance with the increasing amount of ye'elimite in these clinkers (Figure 1b). Ye'elimite was also barely detected in all three hydrated samples, indicating a high degree of hydration. The latter is additionally confirmed by the decreasing amount of gypsum found in the cement pastes containing a higher amount of ettringite. During 28 days hydration of the cement pastes based on clinker mixture $\mathrm{C}$ heated to $1120^{\circ} \mathrm{C}$ and $1220^{\circ} \mathrm{C}$, barely perceptible amounts of ettringite were formed (Figure 5c), likely related to the very low amounts of ye'elimite present in the clinkers. Furthermore, in the cement paste prepared from clinker mixture $\mathrm{C}$ heated to $1320^{\circ} \mathrm{C}$, almost all ye'elimite was hydrated to ettringite. Only a small amount of gypsum remained in this sample, in contrast to the large amounts found in the pastes prepared from clinkers heated at the two lower temperatures, reflecting the low levels of reactive phases identified in these two clinkers. Belite, ternesite, gehlenite and anhydrite were all present as remnant clinker phases in the cement pastes.

It is evident that after 28 days curing, most of the available ye'elimite in the cement pastes had reacted with the gypsum and anhydrite to form ettringite, which defines the early strength of the cement. The greatest amount of ettringite was identified in cements derived from clinker mixture A, followed by mixtures B and C; gypsum levels increased accordingly. The noticeable amount of ternesite in the cement pastes indicates that the degree of ternesite 

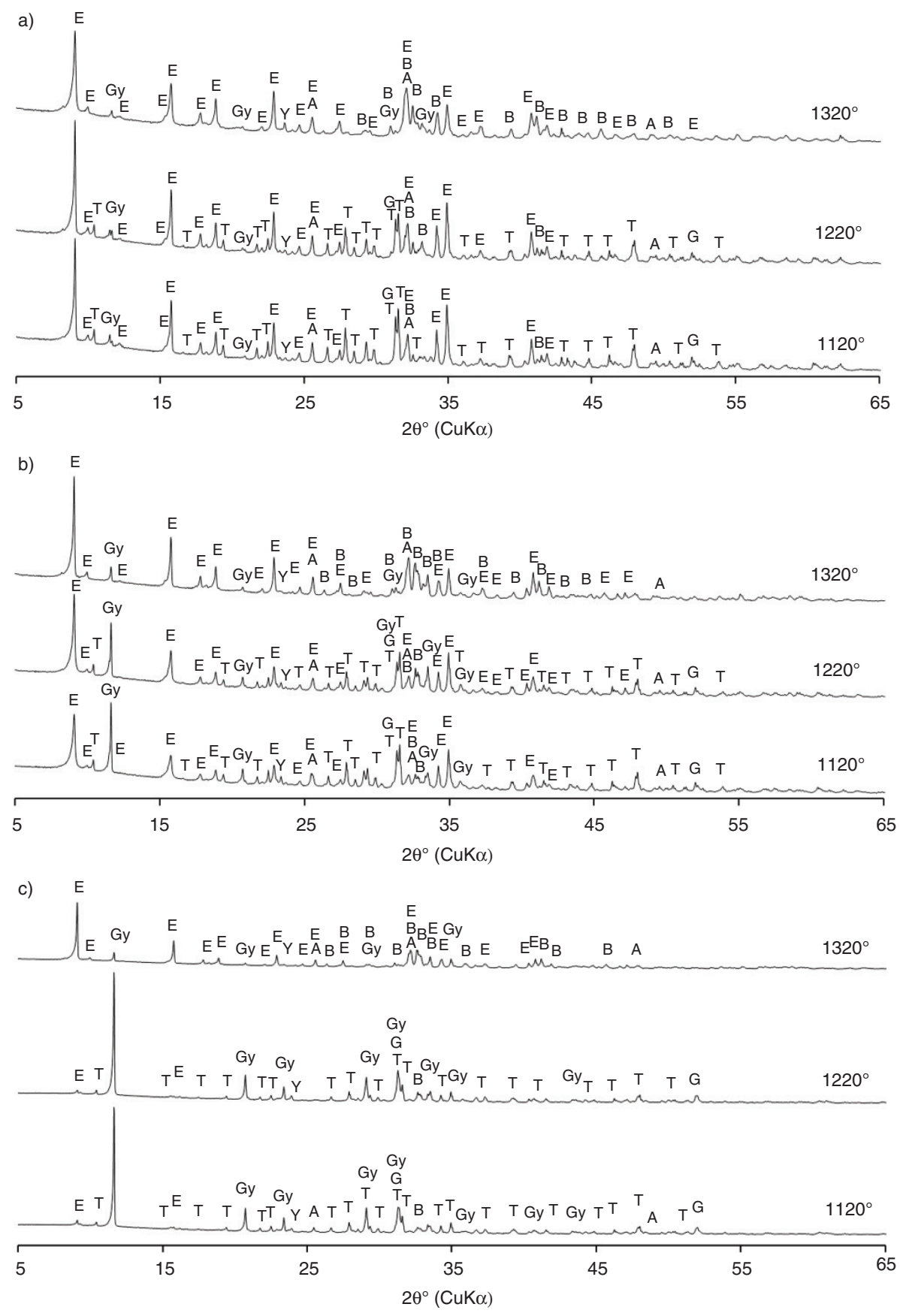

FIGURE 5. X-ray diffraction patterns of cement hydration products after 28 days for clinkers produced from: a) mixture A, b) mixture $\mathrm{B}$ and c) mixture $\mathrm{C}$. Labels for clinker phases: $\mathrm{E}=$ ettringite; $\mathrm{B}=\beta$-belite; $\mathrm{Y}=$ ye'elimite; $\mathrm{F}=$ ferrite; $\mathrm{G}=$ gehlenite; $\mathrm{T}=$ ternesite; $\mathrm{A}=$ anhydrite; $\mathrm{Gy}=$ gypsum.

consumption after 28 days was very low, a result also reported in other studies (20). A similar situation was observed for belite. The presence of anhydrite and gypsum even after 28 days suggests that these minerals would continue to be available to react with ferrite, slightly enhancing cement compressive strength (3). Gehlenite was found in all cement pastes made from low-temperature clinkers $\left(1120^{\circ} \mathrm{C}\right.$ and $\left.1220^{\circ} \mathrm{C}\right)$, potentially forming strätlingite during the later stages of the hydration process (4).

\subsubsection{Compressive strength}

Table 7 displays the compressive strength of the cement pastes obtained after 28 days curing. Cement paste compressive strength depends on the 
TABLE 7. Compressive strength $\left(\mathrm{N} / \mathrm{mm}^{2}\right)$ of cement pastes after 28 days curing.

\begin{tabular}{|c|c|c|c|c|c|c|c|c|c|}
\hline Mixture & \multicolumn{3}{|c|}{$\mathbf{A}$} & \multicolumn{3}{|c|}{ B } & \multicolumn{3}{|c|}{ C } \\
\hline $\mathrm{T}\left({ }^{\circ} \mathrm{C}\right)$ & 1120 & 1220 & 1320 & 1120 & 1220 & 1320 & 1120 & 1220 & 1320 \\
\hline Compressive strength $\left(\mathrm{N} / \mathrm{mm}^{2}\right)$ & 14.8 & 18.3 & 45.8 & 5.9 & 3.5 & 15.9 & 0.5 & 0.2 & 1.6 \\
\hline
\end{tabular}

raw material design of the clinker mixtures, firing temperature and consequent clinker composition.

The cement paste based on clinker mixture A (no substitution of bauxite with fly ash) heated at $1320^{\circ} \mathrm{C}$ presented the greatest compressive strength of $45.8 \mathrm{~N} / \mathrm{mm}^{2}$. This result is closely related to the high levels of the hydration product ettringite found in this particular paste, which in turn reflect the presence of ye'elimite in the clinker mixture. At lower heating temperatures of 1120 and $1220^{\circ} \mathrm{C}$, lower values of compressive strength were obtained, at 14.80 and $18.30 \mathrm{~N} / \mathrm{mm}^{2}$, respectively. Similarly, the compressive strength of the cement paste composed of clinker mixture B (half of bauxite substituted with fly ash) heated at $1320^{\circ} \mathrm{C}$ was higher than that of the lower-temperature clinker mixtures, at $15.90 \mathrm{~N} / \mathrm{mm}^{2}$. The cement pastes based on clinker mixture C (bauxite fully substituted with fly ash) presented the lowest compressive strength of all the tested samples $\left(0.2\right.$ to $\left.1.6 \mathrm{~N} / \mathrm{mm}^{2}\right)$. For the pastes derived from clinkers heated at $1120^{\circ} \mathrm{C}$ and $1220^{\circ} \mathrm{C}$, this weak compressive strength is related to the low amounts of ettringite in the pastes (Figure 5) and low ye'elimite levels in the corresponding clinkers (Figure 1, Table 6). However, it is interesting to note that the compressive strength of the cement paste based on clinker mixture $\mathrm{C}$ heated at $1320^{\circ} \mathrm{C}$ was also low, despite the fact that this paste's ettringite content was comparable to that of the cement pastes based on clinker mixtures A and B (heated at $1320^{\circ} \mathrm{C}$ ). One potential explanation for this result could be delayed ettringite formation $(37,38,39)$. Alternatively, according to Idrissi et al. (36), doping calcium sulfoaluminate with iron seems to slightly reduce the dissolution rate and also the nucleation rate during the induction period. Nevertheless, further study is required to explain this issue.

Generally, the highest values of compressive strength were obtained for the three clinker mixtures subjected to the highest temperature, i.e. $1320^{\circ} \mathrm{C}$, a result in agreement with similar studies reported in the literature (15). The lower compressive strength of the cement pastes composed of clinker mixtures heated at 1120 and $1220^{\circ} \mathrm{C}$ is the result of their phase composition, which did not contribute to cement mechanical properties during the selected curing period of 28 days. Indeed, ternesite hydration is typically very slow and can contribute to a decrease in early strength (7). This is also the case for belite, which is usually present in calcium sulfoaluminate cements, as its hydration is also typically slow but provides long-term strength (1). Furthermore, the poor hydraulic ability of gehlenite means that it contributes little to the compressive strength of a cement (11). The slight decrease in compressive strength of the cement pastes based on clinker mixtures $\mathrm{B}$ and $\mathrm{C}$ heated at $1220^{\circ} \mathrm{C}$ is thus most probably the result of the higher quantity of phases that do not influence cement strength, such as gehlenite and ternesite. These phases were not found in the clinker mixtures obtained at $1320^{\circ} \mathrm{C}$. After 28 days hydration, cement compressive strength was mainly conditioned by the available ye'elimite and gypsum or anhydrite.

\section{CONCLUSIONS}

The present work focuses on the synthesis of belite-sulfoaluminate clinkers incorporating NORM by-products (phosphogypsum and siliceous fly ash). The study characterises the clinkering products obtained at three temperatures (1120, 1220 and $1320^{\circ} \mathrm{C} / 1 \mathrm{~h}$ ), as well as the strength development and hydration behaviour of cement pastes produced using these clinkers.

The main conclusions can be summarised as follows:

- The main clinker phase was highly reactive ye'elimite, followed by slowly reactive belite and ternesite. Ye'elimite and belite content increased with firing temperature. Only a small amount of ye'elimite was detected in clinker mixture $\mathrm{C}$ fired at lower temperatures. In samples containing fly ash, a higher amount of slowly reactive gehlenite phase was present.

- Ye'elimite levels decreased in clinkers with greater bauxite substitution for fly ash, whereas belite and gehlenite content increased accordingly.

- The main hydration product was ettringite, the presence of which was closely related to that of ye'elimite in the clinkers. A higher ye'elimite content in the clinkers resulted in increased ettringite levels and consequently the greater compressive strength of the hydrated paste.

- The highest compressive strength values after 28 days curing were achieved in cement pastes produced using clinkers with the highest firing temperature, i.e. $1320^{\circ} \mathrm{C}$. Clinker mixtures containing a higher amount of fly ash instead of bauxite resulted in lower values of compressive strength $(\mathrm{A}>>>\mathrm{B}>\mathrm{C})$. The lower $\mathrm{Al}_{2} \mathrm{O}_{3}$ content 
of these mixtures was not sufficient for ye'elimite formation and contributed to the depletion of reactive phase formation, i.e. ye'elimite and consequently ettringite.

- The greatest compressive strength of $45.8 \mathrm{~N} /$ $\mathrm{mm}^{2}$ was achieved using clinker heated at $1320^{\circ} \mathrm{C} / 1 \mathrm{~h}$ and containing $20 \mathrm{wt} . \%$ phosphogypsum as the NORM representative. In contrast, the use of clinker heated at the same temperature and with the same phosphogypsum content, but substituting 5 wt. \% bauxite with fly ash, resulted in a decrease in compressive strength to $15.9 \mathrm{~N} / \mathrm{mm}^{2}$.

The present study provides preliminary results regarding the potential use of NORM by-products in the synthesis of environmentally friendly belitesulfoaluminate clinkers. Based on this research it seems that whereas phosphogypsum could be implemented into BSA cement production, siliceous fly ash addition would not contribute positively (at least under the conducted experimental conditions) to early cement mechanical properties. However, due to the tested mixtures' high belite content, which hydrates more slowly and thus contributes to the long-term mechanical strength of the resulting cement, future work will focus on studying the long-term performance of belite-sulfoaluminate cements, mixture optimisation and the radiological properties of the final products.

\section{ACKNOWLEDGEMENTS}

Project No. C3330-17-529035 "Raziskovalci2.0-ZAG-529035" was granted by Ministry of Education, Science and Sport of Republic of Slovenia. The investment is co-financed by the Republic of Slovenia, Ministry of Education, Science and Sport and the European Regional Development Fund. The work was also financially supported by COST Action TU 1301: "NORM for Building materials-NORM4BUILDING" (www. norm4building.org). The Metrology Institute of the Republic of Slovenia is acknowledged for the use of XRF. The authors thank Mojca Skerl and Dušica Tauzes for their help with sample preparation and analysis, as well as NOVA Refractories A.D. Pehchevo, Macedonia.

\section{REFERENCES}

1. Glasser, F.P.; Zhang, L. (2001) High-performance cement matrices based on calcium sulfoaluminate-belite compositions. Cem. Concr. Res. 31, 1881-1886. https://doi. org/10.1016/S0008-8846(01)00649-4.

2. Cuberos, A.J.M; De La Torre, A.G.; Alverez-Pinazo, G.; Martin-Sedeño, M.C.; Schollbach, K.; Pollman, H.; Aranda, M.A.G. (2010) Active Iron-Rich Belite Sulfoaluminate Cements: Clinkering and Hydration. Environ. Sci. Technol. 44, 6855-6862. https://doi. org/10.1021/es101785n.
3. Chen, I.A.; Juenger, M.C.G. (2011) Synthesis and hydration of calcium sulfoaluminate-belite cements with varied phase composition. J. Mater. Sci. 46, 2568-2577. https:// doi.org/10.1007/s10853-010-5109-9.

4. Palou, M.; Majling, J.; Doval, M.; Kozankova, J.; Mojumdar, S.C. (2005) Formation and Stability of Crystallohydrates in the Non-equilibrium System During Hydration of SAB Cements. Ceramics-Silicáty 49 [4], 230-236.

5. Strigač, J.; Palou, M.T.; Krištin, J.; Majling, J. (2000) Morphology and Chemical Composition of Minerals Inside the Phase Assemblage C-C2S-C4A3S-C4AF-CS Relevant to Sulphoaluminate Belite Cements. CeramicsSilicáty 44 [1], 26-34.

6. Roy, D.M.; Silsbee, M.R.; Xie, Z. (1999) Influences of Surplus $\mathrm{SO}_{3}$ in FBC Ash on Formation of Belite-Rich Sulfoaluminate Clinkers, International Ash Utilization Symposium, Center for Applied Energy Research, University of Kentucky, paper\#30.

7. Shen, Y.; Qian, J.; Huang, Y.; Yang, D. (2015) Synthesis of belite sulfoaluminate-ternesite cements with phosphogypsum. Cement Concr. Compos. 63, 67-75. https://doi. org/10.1016/j.cemconcomp.2015.09.003.

8. Ukrainczyk, N.; Frankovič Mihelj, N.; Šipušič, J. (2013) Calcium Sulfoaliminate Eco-Cement from Industrial Waste. Chem. Biochem. Eng. Q. 27 [1], 83-93. http://hrcak. srce.hr/99441.

9. El-Alfi, E.A.; Gado, R.A. (2016) Preparation of calcium sulfoaluminate-belite cement from marble sludge waste. Constr. Build. Mater. 113, 764-772. https://doi. org/10.1016/j.conbuildmat.2016.03.103.

10. Rungchet, A.; Chindraprasirt, P.; Wansom, S.; Pimraksa, K. (2016) Hydrothermal synthesis of calcium sulfoaluminate-belite cement from industrial waste materials. J. Clean. Prod. 115, 273-283. https://doi.org/10.1016/j. jclepro.2015.12.068.

11. Wang, W.; Wang, X.; Zhu, J.; Wang, P.; Ma, C. (2013) Experimental Investigation and Modeling of Sulfoaluminate Cement Preparation Using Desulfurization Gypsum and Red Mud. Ind. Eng. Chem. Res. 52, 12611266. https://doi.org/10.1021/ie301364c.

12. Jewell, R.B.; Rathbone, R.F.; Duvallet, T.Y.; Robi, T.L.; Mahboub, K.C. (2015) Fabrication and Testing of LowEnergy Calcium Sulfoaluminate-Belite Cements that Utilize Circulating Fluidized Bed Combustion By-Products. Coal Combustion and Gasification Products Journal. 7, 9-18. https://doi.org/10.4177/CCGP-D-15-00001.1.

13. Arjunan, P.; Silsbee, R.M.; Roy, D.M. (1999) Sulfoaluminate-belite cement from low-calcium fly ash and sulfur-rich and other industrial by-products. Cem. Concr. Res. 29, 1305-1311. https://doi.org/10.1016/ S0008-8846(99)00072-1.

14. Ma, B.; Li, X.; Mao, Y.; Shen, X. (2013) Synthesis and characterization of high belite sulfoaluminate cement through rich alumina fly ash and desulfurization gypsum. Ceramics - Silikáty. 57 [1], 7-13.

15. Gallardo, M.; Almanza, J.M.; Cortés, D.A.; Escobedo, J.C.; Escalante-García, J.I. (2014) Synthesis and mechanical properties of a calcium sulphoaluminate cement made of industrial wastes. Mater. Construc. 64 [315], 1-8 https:// doi.org/10.3989/mc.2014.04513.

16. Ren, C.; Wang, W.; Li, G. (2017) Preparation of highperformance cementitious materials from industrial solid waste. Constr. Build. Mater. 152, 39-47. https://doi. org/10.1016/j.conbuildmat.2017.06.124.

17. Álvarez-Pinazo, G.; Cuesta, A.; García-Maté, M.; Santacruz, I.; Losilla, E.R.; Dela Torre, A.G.; LeónReina, L.; Aranda, M.A.G. (2012) Rietveld quantitative phase analysis of yeelimite-containing cements. Cem. Concr. Res. 42 [7], 960-971. https://doi.org/10.1016/j. cemconres.2012.03.018.

18. Martín-Sedeño, M.C.; Cuberos, A.J.M.; De la Torre, Á.G.; Álvarez-Pinazo, G.; Ordónez, L.M.; Gateshki, M.; Aranda, M.A.G. (2010) Aluminum-rich belite sulfoaluminate cements: Clinkering and early age hydration. Cem. Concr. Res. 40, 359-369. https://doi.org/10.1016/j. cemconres.2009.11.003. 
19. Beretka, J.; de Vito, B.; Santoro, L.; Sherman, N.; Valenti, G.L. (1993) Utilisation of industrial wastes and by-products for the synthesis of special cements. Resour. Conserv. Recy. 9, 179-190. https://doi.org/10.1016/0921-3449(93)90002-W.

20. Bullerjahn, F.; Schmitt, D.; Haha, M.B. (2014) Effect of raw mix design and clinkering process on the formation and mineralogical composition of (ternesite) belite calcium sulphoaluminate ferrite clinker. Cem. Concr. Res. 59, 87-95. https://doi.org/10.1016/j.cemconres.2014. 02.004

21. Bullerjahn, F.; Zajac, M.; Ben Haha, M. (2014) CSA raw mix design: effect on clinker formation and reactivity. Mater. Struct. 48 [12], 3895-3911. https://doi.org/10.1617/ s11527-014-0451-z.

22. Hanein, T.; Galanb, I.; Glasser, F.P.; Skalamprinos, S.; Elhoweris, A.; Imbabi, M.S.; Bannerman, M.N. (2017) Stability of ternesite and the production at scale of ternesite-based clinkers. Cem. Concr. Res. 98, 91-100. https:// doi.org/10.1016/j.cemconres.2017.04.010.

23. Kasselouri, V.; Tsakiridis, P. (1995) A study on the hydration products of a non-expensive sulfoaluminate cement. Cem. Concr. Res. 25 [8], 1726-1736. https://doi. org/10.1016/0008-8846(95)00168-9.

24. Chen, I.A.; Juenger, M.C.G. (2012) Incorporation of coal combustion residuals into calcium sulfoaluminate-belite cement clinkers. Cement Concr. Compos. 34, 893-902. https://doi.org/10.1016/j.cemconcomp.2012.04.006.

25. Álvarez-Pinazo, G.; Santacruz, I.; Leon-Reina, L.; Aranda, M.A.G.; De la Torre, A.G. (2013) Hydration Reactions and Mechanical Strength Developments of IronRich Sulfobelite Eco-cements. Ind. Eng. Chem. Res. 52, 16606 16614. https://doi.org/10.1021/ie402484e.

26. J. Labrincha, F Puertas, W. Schroeyers, K. Kovler, Y. Pontikes, C. Nuccetelli, P. Krivenko, O. Kovalchuk, O. Petropavlovsky, M. Komljenovic, E. Fidanchevska, R. Wiegers, E. Volceanov, E. Gunay, M.A. Sanjuan, V. Ducman, B. Angjusheva, D. Bajare, T. Kovacs, G. Bator, S. Schreurs, J. Aguiar, J.L. Povis (2017) From NORM by-products to building materials, In Schroeyers, W. (ed) Naturally Occurring Radioactive Materials in Construction, Integrating Radiation Protection in Reuse (COST Action Tu1301 NORM4BUILDING).Woodhead Publishing Series in Civil and Structural Engineering, Elsevir.

27. Saadaoui, E.; Ghazel, N.; Romdhane, C.B.; Massoudi, N. (2017) Phosphogypsum: potential uses and problems-a review, International Journal of Environmental studies, 1-10. https://doi.org/10.1080/00207233.2017.1330582.

28. EN 196-2:2013, Method of testing cement. Chemical analysis of cement.
29. Javellana,M.;Jawed,I.(1982)Extraction of freelimein Portland cement and clinker by ethylene glycol. Cem. Concr. Res. 12, 399-403. https://doi.org/10.1016/0008-8846(82)90088-6.

30. Galan, I.; Hanein, T., Elhoweris, A.; Bannerman, M.N.; Glasser, F.P. (2017) Phase Compatibility in the System CaO$\mathrm{SiO}_{2}-\mathrm{Al}_{2} \mathrm{O}_{3}-\mathrm{SO}_{3}-\mathrm{Fe}_{2} \mathrm{O}_{3}$ and the Effect of Partial Pressure on the Phase Stability. Industrial \& Engineering Research. 56, 2341-2349. https://doi.org/10.1021/acs.iecr.6b03470.

31. Marroccoli, M.; Pace M.L; Telesca, A. Valenti, G.L. (2010) Synthesis of calcium sulfoaluminate cements from $\mathrm{Al}_{2} \mathrm{O}_{3}$-rich by-products from aluminum manufacture, in: Proceedings of the $2^{\text {ed }}$ International Congress on Sustainable Construction Materials and Technologies, Ancona, Italy, 2010.

32. Jen, G.; Skalamprinos, S.; Whittaker, M.; Galan, I.; Ibabai, M.S.; Glasser, F.P. (2017) The impact of intrinsic anhydrite in an experimental calcium sulfoaluminate cement from a novel, carbon-minimized production process. Mater. Struct. 50, 144. https://doi.org/10.1617/s11527-017-1012-z.

33. Brotherton, P.D.; Epstein, J.M.; Pryce, M.W.; White, A.H. (1974) Crystal Structure of Calcium Sulphosilicate $\mathrm{Ca}_{5}\left(\mathrm{SiO}_{4}\right)_{2} \mathrm{SO}_{4}$. Aust. J. Chem. 27, 657-660. https://doi. org/10.1071/CH9740657.

34. Shermanl, N.; Beretkal, J.; Santoro, L.; Valenti, G.L. (1995) Long-term behaviour of hydraulic binders based on calciumsulfoaluminate and calcium sulfosilicate. Cem. Concr. Res. 25 [1], 113-126. https://doi.org/10.1016/0008-8846(94)00119-J.

35. Idrissi, M; Diouri, A.; Damidot, D.; Greneche, J.M.; Talbi, M.A.; Taibi, M. (2010) Characterisation of iron inclusion during the formation of calcium sulfoaluminate phase. Cem. Concr. Res. 40, 1314-1319. https://doi.org/10.1016/j. cemconres.2010.02.009.

36. Idrissi, M; Diouri, A. Talbi, M.A.; Sassi, O; Taibi, M. Damidot, D. (2012) Hydration behavior of iron doped calcium sulfoaluminate phase at room temperature. MATEC Web of Conferences 2. https://doi.org/10.1051/ matecconf/20120201005

37. Gallardo H., M.; Almanza R., J.M.; Cortés H., D.A.; Escobedo B., J.C. (2016) Mechanical and chemical behavior of calcium sulfoaluminate cements obtained from industrial waste. Revista ALCONPAT 6, 15-27, https:// doi.org/10.21041/ra.v6i1.112.

38. Taylor, H.F.W.; Famy, C.; Scrivener, K.L. (2016) Delayed ettringite formation. Cem. Concr. Res. 31, 683-693. https:// doi.org/10.1016/S0008-8846(01)00466-5

39. Kaufmann, J.; Winnefeld, F.; Lothenbach, B. (2016) Stability of ettringite in CSA cement at elevated temperatures. Adv. Cem. Res. 28, 251-261. https://doi.org/10.1680/ jadcr.15.00029. 